\title{
THE BLOODSHED IN NORTH HALMAHERA: Roots, Escalation, and Reconciliation
}

\author{
USMAN $^{1}$
}

\begin{abstract}
This paper aims to explain the conflict on North Maluku Island or North Halmahera in I999 to be more specific. When compared with the conflict in Ambon, the conflict in North Halmahera is much greater in terms of the number of victims and material losses. There are several factors that influenced the conflict such as politics, economics and religion. It seems that politics and religion were the dominant underlying factors of the conflict.At that time, the mass media did not report the conflict effectively, so that the resolution of the conflict came too late and the conflict escalated and spread to the entire region of North Maluku. The most fundamental thing causing the conflict was associated with regional growth (pemekaran), namely the emergence of a new sub-district within the existing sub-district of Kao. The new sub-district was created by the Makian, who are migrants from the island of Kie Besi in North Maluku. They pushed the government to establish a new sub-district of Makian Daratan within the sub-district of Kao. The Pagu people,natives to the area, rejected the regional growth. There was a demonstration that ended in a fight between the Pagu and the Makian. Coincidentally, most of the Pagu are Christian and all of theMakian areMuslim. This led to religious issues becoming a factor with certain parties. As a result, this was a horizontal conflict wrapped with religious issues. In terms of methodology, this paper was written using a qualitative approach that produces descriptive data about the conflicts in North Halmahera. The analysis of the field data was undertaken using some theories of conflict. As a conclusion it can be stated that the conflict in North Halmahera is basically a conflict of interest that is wrapped with religious issues.
\end{abstract}

Keywords: horizontal conflict, North Halmahera, escalation, and regional growth.

\begin{abstract}
Abstrak
Artikel ini ingin menjelaskan tentang konflik yang terjadi di Pulau Maluku Utara, tepatnya di Halmahera Utara di tahun 1999. Jika dibandingkan dengan konflik yang terjadi di Ambon, konflik di Halmahera Utara jauh lebih besar karena banyaknya jumlah korban dan kerugian material. Ada beberapa faktor yang mempengaruhi konflik itu terjadi. Dari sekian faktor tampaknya faktor politik dan faktor agama menjadi hal dominan yang melatarbelakangi konflik itu terjadi. Pada saat itu, media massa kurang gencar melakukan reportase terhadap konflik tersebut, sehingga penyelesaian konflik menjadi terlambat dan konflik telah mengalami eskalasi dan tersebar ke seluruh wilayah Maluku Utara. Hal paling mendasar yang menyebabkan konflik itu terjadi terkait dengan pemekaran wilayah, yaitu munculnya Kecamatan baru di wilayah Kecamatan Kao. Kecamatan baru itu diusung oleh orang-orang Makian yang notabene adalah para pendatang dari Pulau Kie Besi di wilayah Maluku Utara. Mereka mendorong pemerintah untuk menetapkan Kecamatan Makian Daratan yang letaknya berada di Kecamatan Kao. Orang-orang Pagu sebagai penduduk asli menolak pemekaran tersebut. Kemudian terjadi demonstrasi yang berakhir pada perkelahian antara orang Pagu dan Orang Makian. Secara kebetulan, sebagian besar orang Pagu beragama Kristen dan orang makian beragama Islam, maka isu-isu agama pun mulai dimainkan oleh pihak-pihak tertentu. Akibatnya, terjadilah konflik horizontal yang dibalut dengan isu agama. Dari segi metodologis, artikel ini ditulis dengan memakai pendekatan kualitatifyang menghasilkan data deskriptif tentang konflik horizontal di Halmahera Utara. Analisis terhadap data lapangan dilakukan dengan memakai beberapa teori konflik. Dapat ditarik simpulan bahwa konflik di Halmahera Utara pada dasarnya adalah konflik kepentingan yang dibalut dengan isu agama.
\end{abstract}

Kata Kunci: konflik horizontal, Halmahera Utara, eskalasi, dan pemekaran wilayah.

I Researcher at Research Center for Society and Culture, Indonesian Institute of Sciences (LIPI), Jakarta. Indonesia. Email: asyqi_wahidi@yahoo.com

Copyright $\bigodot_{20 I 6}$ The Author, (20I6 Deputy of Social Sciences and Humanities. All rights reserved. Printed in Indonesia.

Journal of Indonesian Social Sciences and Humanities (JISSH); Vol. 6, Issue 2, (20I6), Pp. I-II. ISSN: I979-843I. 


\section{INTRODUCTION}

The conflict in North Halmahera took place in I999. It began in the Malifut sub-district and spread to Tobelo and other regions in North Maluku. After the conflict the social conditions became full of tension and distrust. This was triggered by a series of conflicts in North Halmahera in particular and North Maluku in general. Some scholars have suggested that the conflict in North Halmahera was a consequence of the conflict in Ambon which happened on January I999. (Chris Wilson, 2005: 70). The cause of the Ambon conflict wassimple: there was a personal fight between an Ambon native and a migrant from South Sulawesi. The conflict then changed to the issue of religion between Muslims and Christians. I will briefly explain the dispute in Ambon with the hope of finding the best solution to end Halmahera conflict.

There have been disagreements among the scholars about the real cause of the conflict. Some scholars believe that the conflict in North Halmahera was due to the political issues of territorial extension. Christopher R. Duncan, for example, asserted that "the North Halmahera conflict revolved around the passage of government regulation No. 42/1999 that gives birth to a new sub-district Malifut for the Makian in the Southern part of the sub-district Kao" (Christopher R. Duncan, 2005: 6r; (Chris Wilson, 20015:70). Before the territorial extension period, people called Malifut as Sosol: a village belonging to the region of Kao. The Makian rejected PP No. 42 for many reasons: politics, economy, and ethnic dominion. Therefore, no single reason caused the North Halmahera conflict.

There has never been a conflict purely caused by religion. Some conflicts, however, manipulate the issue of religion so as to hurt another party. The North Halmahera conflict is an example of this, which show how religious factors can make the fights bloodier. According to Chris Wilson, "The bleeding of North Halmahera led to the deaths of around 3000 victims, the internal displacement of 250000 people (mostly Makian) and the destruction of approximately 20000 houses, places of worship, and other buildings."(Chris Wilson, 2005:I).
Thus, this paper will focus on three research questions. Firstly, what were the causes that led the bloody conflict in Northern Halmahera? Secondly, how did the escalation of the conflict take place? Thirdly, how did the process of reconciliation work?

\section{APPROACH AND METHODS}

This paper was written with a qualitative approach that produces descriptive data. The data is based on a literature review and in-depth interviews with key informants from the sub-districts of Kao, Malifut and others. The data and findings of thefield trip was analyzed using some concepts proposed by theorists such as R. Scott Appleby, Ashutosh Varshney, and Mohammad Zulfan Tadjoeddin.

About peace building and reconciliation, Tadjoeddin offers three hypotheses that can be used to analyze communal conflict in the context of Indonesian civil society. He follows a conceptual framework proposed by Ashutosh Varshney,which is known as inter-communal civic engagement. Then he develops his conceptual framework considering the nature of the Indonesian civil society, namely (a) the highly segregated setting of the community, (b) the paternalistic structure of the society, and (c) the fact that communal violence is usually triggered by a clash at the individual level. (Tadjoeddin, 2004: II). Finally, he proposes three civil society mechanisms; these are inter-communal civic engagement, self (community) policing, and elite integration (Tadjoeddin 2004:I-2). Tadjoeddin's conceptual framework can be seen in the diagram below. These three engagements cannot be separated. These are the three engagements which will be used to analyze the conflict in North Halmahera.

Engagement is done among the elite (I) so that they are integrated. This role is important because they have the power to manage others. Self-policing in a community is a basic start to manage each group. Strong engagement in a group and deescalating the conflict within thegroup is necessary (A and B). Afterwards inter-communal engagement is undertaken as a way to make peace in a broadercontext. This engagement can only be done once the elite 
Figure 3

HYPOTHESIS ON HYPOTHESES

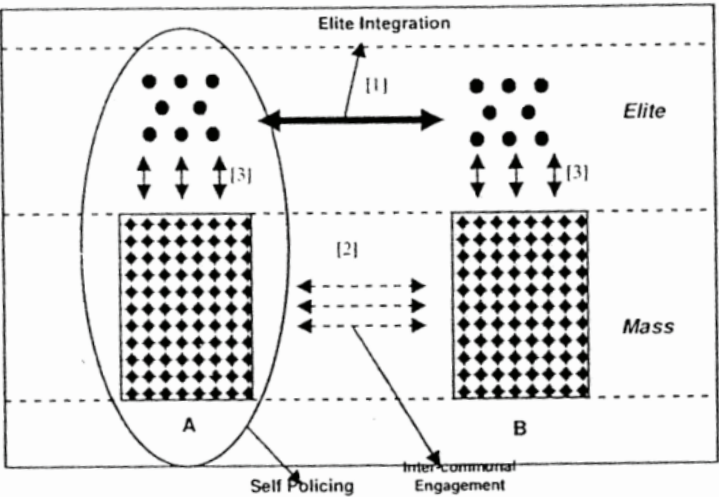

*Source: Tadjoeddin, Mohamad Zulfan. "Civil Society Engagement and Communal Violence: Reflection on Various Hypotheses in the Context of Indonesia," 2004.

integration and self-policing have worked (2). The elite and the masses also need to integrate. (3). Those engagements were attempted in Northern Halmahera. It is a challenge to integrate after the conflict was deescalated.

\section{RESULT AND DISCUSSION}

\section{Finding the Root of Conflict} Impact of the Ambon Conflict

The North Halmahera conflict cannot be separated from the horizontal conflict in Ambon. After a war between Islam and Christianity had broken out in Ambon, some residents from Ambon went to Ternate, Tidore, Tobelo, North and West Halmahera. They came to North Maluku without creating any social unrest. In addition to the refugees, natives from the island of Halmahera, who had lived in Ambon for several years, returned to their homes. For example, one Muslim man who had been living in Ambon went home to his village of Talaga in West Halmahera where the majority of residents are Muslim. After arriving at his village, he told the story of conflict happened in Ambon. Some people felt angry because of the religious sentiments was dominant in these stories. As aresult, in the middle of June i999, a small incident between some youths took place in the village of Talaga. There were no victims or material losses. (Jan Nanere, 200o)
A second incident happened in the same village on June 22 and 23, I999. (Martin Budiman, 2009). It was a fight between Muslim and Christian youths. In this conflict a young person from the village of Talaga was killed. Residents immediately reported the incident to the security forces to control the situation. The conflict was successfully resolved, and it did not spread to other sub-districts. (Jan Nanere, 2000: 55-56). The following table shows the chronology of the conflict in West Halmahera:

Table I: Conflict Escalation in West Halmahera

\begin{tabular}{|c|c|c|c|c|}
\hline Date & Violence & Place & Victim & Consequence \\
\hline $\begin{array}{l}\text { Middle } \\
\text { of June } \\
1999\end{array}$ & $\begin{array}{l}\text { Residents are } \\
\text { fighting. }\end{array}$ & $\begin{array}{l}\text { The Village of } \\
\text { Talaga, Sub- } \\
\text { district Ibu, } \\
\text { West Halma- } \\
\text { hera regency. }\end{array}$ & No victims & $\begin{array}{l}\text { Religious senti- } \\
\text { ments increase. }\end{array}$ \\
\hline $\begin{array}{l}\text { June 22, } \\
1999\end{array}$ & $\begin{array}{l}\text { Fights be- } \\
\text { tween Mus- } \\
\text { lim (village } \\
\text { of Talaga) } \\
\text { and Chris- } \\
\text { tian (village } \\
\text { of Bataka) } \\
\text { youths. }\end{array}$ & $\begin{array}{l}\text { The market of } \\
\text { Talaga. }\end{array}$ & No victims & $\begin{array}{l}\text { - Christian } \\
\text { residents were } \\
\text { angry. } \\
\text { - Head of } \\
\text { Bataka's village } \\
\text { succeeds to } \\
\text { overcome the } \\
\text { problem for a } \\
\text { while. }\end{array}$ \\
\hline $\begin{array}{l}\text { June 23, } \\
1999\end{array}$ & $\begin{array}{l}\text { Attack on } \\
\text { Bataka vil- } \\
\text { lage. }\end{array}$ & Bataka Village & $\begin{array}{l}\text { One person } \\
\text { fromTalaga } \\
\text { killed. }\end{array}$ & $\begin{array}{l}\text { Security forces } \\
\text { intervened to } \\
\text { reconcile. }\end{array}$ \\
\hline
\end{tabular}

* Nanere, Jan (et.al), Kerusuhan Maluku Seri Pertama: Halmahera Berdarah, 2000.

Based on Table I, we can say that the conflict in Halmahera was impacted from the conflict in Ambon, the incidents were limited to one sub-district, and it also did not start other conflicts in other sub-districts. In other words, we can say that the scale of the conflict was very narrow. This conflict did not spread to other sub-districts because they have lived together in harmony for decades. So, the religious issue did not cause them to fight to each other. Besides, the government responded quickly to this conflict and resolved it amicably.

\section{Proposing a New Sub District}

According to Efrida Erna Ngato, the leader of the ethnic Pagu, the North Maluku conflict was initially caused by the Makian who attacked the Pagu in the village of Sosol. The attack took place in August I999. In the first attack, the 
Makian destroyed a number houses owned by the Pagu. There were at least two people killed during this attack. The first victim was Elieser Moumuo, who was the father of the village chief of Sosol. The second victim was Eras Dodowol. Other sources claimed that in the first attack there were two more people killed, namely: BernarToloa and Hanok Lasa. (Jan Nanere, 2000: 58).

After the first incident, the Pagu people living in other villages were frightened. They gathered and fled to Kao sub-district. They moved to Kao because it has a port that could let them escape by sea. By this time, the land was fully controlled by the Makian. It is important to note here that Kao sub-district was mostly inhabited by Muslims from a Kao ethnic background. When the Pagu fled to Kao, it was clear that the conflict was not purely religious.

Furthermore, Ms. Ngato explained that the conflict was triggered by the government's territorial extension. (Interviews, 2013). The Government Regulation of PP No. 42 of 1999 regulates a new sub-district named Makian Daratan. Before the territorial extension, this region had 22 villages, five of them inhabited by the natives, and I7 others inhabited by the Makians. Talking about identity, the Makian are divided into two categories; West Makian and East Makian. Although they believe in the same religion, they speak in different languages. West Makian people speak a non-Austronesian language while East Makian people speak an Austronesian language. To communicate with each other, Makian people use the popular LinguaFranca, which is considered as the Malay Ternate language.

The first arrival of the Makian in North Halmahera Island began in 1975 when the North Maluku provincial government issued a policy to send Makian people from Makian Island to North Halmahera Island. These displacements were due to the eruption of Mount Kie Besi located on Makian Island. Besides, North Halmahera Island needed more people to work on the developing plantations owned by the Makian. Through this local transmigration program, all Makian people from Makian Island were sent to North Halmahera. (Interview with
Makian people, 20Io). According to independent sources, the government often made repressive actions during this process of immigration. For example, the military forced the inhabitants to move to the North Halmahera Island as soon as they possibly could. Of course, the government had built the infrastructure facilities such as housing and land for the Makian to live. Those local transmmigrants could possess a piece of land approximately i to 3 acres. The local transmigration program lasted approximately 5 years.

After moving to North Halmahera Island, the Makian interacted with the native residents of the area. Practically speaking, there were no serious problems when they interacted with the native people. The number of Makian immigrants was so huge that they occupied in seventeen villages. Administratively they were under the control of the sub-district Kao. From I975 until I998 there was no serious conflict between the Makian and the native ethnics such as the Pagu, Modole, Boeng or Towiliko (Interview with Makian people, 20Io). According to Makian sources, at the beginning of local transmigration program, the Makia ns met native ethnics who still inhabited in the forests. In 1975 there were still many native ethnics in the Malifut area living in the forests with no permanent houses.

Social interactions between the Makian and the Pagu encouraged the Pagu to build permanent houses. In other words, the Pagu learned many things from the Makian. On one hand the Pagu gave a lot to the Makian, on the other hand, the Makian taught the Pagu how to build houses, how to cultivate the land for plantations, and how to increase the productivity of land. The long peaceful interaction between the immigrants and the natives brought positive impacts on both sides. For example, the Pagu gave the Makian a chance to cultivate their land for free. The Makian did not want to take advantage of this by cheating the Pagu (Interview with Makian people, 20Io).

The Makian's work ethos and better skills led them to greater success in economic life compared with the native ethnics. Their success was reflected by the amount of land owned by 
the Makian. On average,one Makian person had 3 hectares. Some of them already owned more than 30 hectares. From this, we can calculate their economic income because their land is very productive. For instance, they grew copra and cloves together in the same plantation, or they planted copra and nutmeg together in other plantations. In brief, the Makian's rapid economic development required a new subdistrict to support the momentum. Therefore, they proposed to the government to form a new sub-district, Makian Daratan. In the beginning, the government did not agree with this idea, but the Makian's strong political lobbies made the government issued PP No. 42/1999 (Interview with Makian people, 20Io).

Unfortunately, the native ethnics rejected PP No. 42/1999. They thought that it was impossible for the Makian to have a sub-district in North Halmahera Island because it was not legal. The first reason to reject PP No. 42/I999 was the name of the new sub-district, Makian Daratan. Some people thought the new name suggested issues of identity and ethnic dominion. Tensions began to increase gradually (Interview with the leader of the Pagu people). Table 2 shows the map of conflict escalation caused by the presence of the new sub-district:

Table 2: The conflict escalation in North Halmahera

\begin{tabular}{|c|c|c|c|c|}
\hline Date & Violence & Place & Victims & Consequence \\
\hline 1982 & Fighting among residents. & Malifut & $\begin{array}{l}\text { Victims killed on both } \\
\text { sides. }\end{array}$ & $\begin{array}{l}\text { Peaceful agreement } \\
\text { based on tradition } \\
\text { laws. }\end{array}$ \\
\hline $\begin{array}{l}\text { March } \\
1999\end{array}$ & $\begin{array}{l}\text { Some Makian students helda } \\
\text { demonstration to protest the } \\
\text { new sub-district. }\end{array}$ & $\begin{array}{l}\text { The DPRD office } \\
\text { of Ternate. }\end{array}$ & No victims. & $\begin{array}{l}\text { DPRD gave no atten- } \\
\text { tion. }\end{array}$ \\
\hline $\begin{array}{l}\text { March } \\
1999\end{array}$ & $\begin{array}{l}\text { Another demonstration by } \\
\text { the Makian. }\end{array}$ & $\begin{array}{l}\text { The sub-district } \\
\text { of Kao. }\end{array}$ & No victims. & Both sides felt angry. \\
\hline $\begin{array}{l}\text { March } \\
1999\end{array}$ & $\begin{array}{l}\text { The Pagu destroyed some } \\
\text { symbols of new sub-district. } \\
\text { It is the trigger of the conflict. }\end{array}$ & Malifut & No victims. & $\begin{array}{l}\text { The Makians were } \\
\text { angry. }\end{array}$ \\
\hline $\begin{array}{l}\text { August 18, } \\
1999\end{array}$ & $\begin{array}{l}\text { The Makian attacked the } \\
\text { Pagu. It is the beginning of } \\
\text { conflict violence. }\end{array}$ & Sosol & $\begin{array}{l}\text { Four people killed } \\
\text { (Elieser Moumou, Eras } \\
\text { Dodowol, BernarToload- } \\
\text { an, \&Hanok Lasa). Some } \\
\text { Pagu houses destroyed. }\end{array}$ & The Pagus were angry. \\
\hline $\begin{array}{l}\text { August 19, } \\
1999\end{array}$ & $\begin{array}{l}\text { Another attack by the Ma- } \\
\text { kian. }\end{array}$ & $\begin{array}{l}\text { Sosol and Wan- } \\
\text { geotak }\end{array}$ & Incendiarism. & $\begin{array}{l}\text { Jihad is called from } \\
\text { the mosque. } \\
\text { The Pagu moved to } \\
\text { Kao. }\end{array}$ \\
\hline $\begin{array}{l}\text { August 20, } \\
1999\end{array}$ & $\begin{array}{l}\text { The Pagu, supported by other } \\
\text { native ethnics from West and } \\
\text { East Kao, protect their terri- } \\
\text { tory from the Makian. }\end{array}$ & Kao & No victims. & $\begin{array}{l}\text { Preparation to coun- } \\
\text { terattack. }\end{array}$ \\
\hline $\begin{array}{l}\text { The late } \\
\text { August } \\
1999\end{array}$ & $\begin{array}{l}\text { Sultan of Ternate stopped } \\
\text { the Pagu for attacking the } \\
\text { Makian. }\end{array}$ & Malifut & $\begin{array}{l}\text { Dozen people killed } \\
\text { from both sides. }\end{array}$ & $\begin{array}{l}\text { The Pagu forced } \\
\text { Sultan to send the } \\
\text { Makian out of Malifut. }\end{array}$ \\
\hline $\begin{array}{l}\text { November } \\
1999\end{array}$ & $\begin{array}{l}\text { The Pagu, supported by other } \\
\text { native ethnics from West and } \\
\text { East Kao, attacked the Makian } \\
\text { They brought machetes, } \\
\text { spears, arrows, bombs, guns } \\
\text { and stone. } \\
\text { It was the peak of violence } \\
\text { in North Halmahera diffusing } \\
\text { over many regions in North } \\
\text { Maluku. }\end{array}$ & Malifut and Kao & Thousand killed. & $\begin{array}{l}\text { Makian moved to } \\
\text { Ternate Island and } \\
\text { other islands in North } \\
\text { Maluku. }\end{array}$ \\
\hline
\end{tabular}

** Nanere, Jan (et.al), Kerusuhan Maluku Seri Pertama: Halmahera Berdarah, 2000. 


\section{Analysis of Conflict Escalation}

The seed of social unrest began to grow when the Governor issued a government regulation, PP No 42, in 1999, that arranged aterritorial extension of Malifut. Five villages declared not to fuse with the new territory of Makian Daratan for many reasons. One main reason was that they questioned the change of name from Kao Raya to Makian Daratan. The government passed the regulation as it knew that Makian people already owned most of the area. (Chris Wilson, 2005: 70).

In June 1999 demonstrations to protest this regulation took place several times. The new name hurt the local people's identity. They were not ready to lose their land. As transmigrants, the Makians worked very hard for years. Thus, they were successful in many kinds of business. When they had owned a lot of land and properties, they proposed to name their land with Makian Daratan. It was during this unrest when many Christian refugees came from Ternate and Tidore. These refugees brought the stories of religious conflicts from their hometowns. Tensions between Christians and Muslims were escalating. Forkom Pemuda Kristen Halmahera dan Gemahilo (Forkom PKH, Christian Youth Forum of Halmahera) suggested that the ethnics of Makian, Kayoa and Tidore leave Tobelo to avoid conflicts. Head of the sub-district of Tobelo, however, rejected the idea saying that 'a provocateur from outside' had arrived at Tobelo. (Martin Budiman, 2009).

It is interesting to examine how the incumbent political leaders and the security forces led tensions to grow among residents. Provocateurs brought the tension further with the distribution of intimidating pamphlets among residents. The pamphlets tell Christians to stay at home because there will be a bloody Christmas night. Other pamphlets tell Muslims to be watchful of the Christian attacks coming very soon. (Martin Budiman, 2009: 15).

When the tension between Christians and Muslims was high, the 'provocateurs' threw stones at a church on December 26, I999. (Interview with Ms. Ngato). A series of conflicts took place on the following three days as tensions began to escalate. The conflicts grew up from light to heavy. The stone throwing at the church was retaliated by the burning of a house. The small incident of stone throwing at the church intensified into looting of shops. The escalation of tensions transformed from specific to general: stone throwing at a church transformed into communal religious conflict. (Martin Budiman, 2009: I6).

The labeling of the Christian group as the red, 'obet', and of the Muslim group as white, 'acang' showed the escalation of conflicts had transformed from winning to hurting. (Interview with Makian, 2010). At this stage of escalation, human beings were not considered as God's unique creations any longer. They were put together from a distance as an enemy with no names, and no rights to exist. This iscalled deindividuation where human beings are considered as non-living objects (enemies) that can be eliminated. Once people are deindividuated they seem less human than those who are individuated. Deindividuation was probably at work in an experiment by Milgram (I974). Deindividuation is analternative process in the circle of conflict escalation. It is useful for people to legitimize and to rationalize their initial contentious moves or to justify violence to others.

Then comes antagonism that manifests in the forms of anger, prejudice, and negative attitudes. As antagonism tends to be reciprocated, the act of hurting enemies transforms from few to many. The act of hurting enemies went wider because the legitimacy of security forces was weak. The police and the ground forces were not able to stabilize the situation. In a formal meeting of November 3, I999, Musriyono Nabiu criticized the unfruitful works of the security forces by saying, 'With 350 friends of mine I am ready to take over the responsibility to restore Tobelo to peace.' (Jan Nanere, 200o).

The arrival of Laskar Jihad, a Muslim militia group, in Tobelo made the situation worse. The conflicts focused on religious aspects. A story of three women from Halmahera who received God's message to attack Muslims was widely told among Christians (Interview with Pagu people, 2010). When religion plays a role in a conflict, they will make the dispute will become 
more devastating because religions create blind obedient people. The following situations in Halmahera made violence take place easily:

I) There were no established procedures to mediate the conflicts

2) There were no rules to prevent preemptive behaviors

3) There was no sense of community

The inability of political, religious and ethnic leaders to mediate the conflict at its earliest stage brought their people to conflicts at an increasing speed. Why the security leader of PHH Yonef 5I2 Brawijaya let Laskar Jihad to enter Tobelo was still a big question for many people. That controversial decision led the Jakarta headquarters to change the security leader of PHH Yonef 512 Brawijaya. No political, religious or ethnic leaders organized any movements to reconcile. No mediators had the capability to bring the two groups to a peaceful agreement. Hatred and retaliations obscured the localwisdom of bahiriono (help each other), soloha (give to each other) and higaro (negotiation).

Community settlements inherited from the Dutch colonialism separated Christians from Muslims. Living in separate neighborhoods made social engagement difficult. It is clear then why tensions and conflicts easily emerge. Varshney (200I) says that civic engagement between two communities is the most important aspect of eliminating tensions and conflicts.

From the explanation above it can be seen that it is impossible for us to find the provocateur behind the conflict of Halmahera. There have been many opinions and analysis that are opposing to one another. Both Muslims and Christians, however, agree that there was a provocateur during the conflicts. The following facts assure their opinions:

I) The story of three women from Halmahera who received God's message to attack the Moslems

2) The distribution of mini Bibles as a mascot during the conflicts

3) The distributions of pamphlets that intimidate both Christians and Muslims
4) The labeling of Christian group as the red, 'obet' and of Muslim group as the white, 'acang'

The role of either political or religious leaders is of utmost importance in creating peace in the community. People do not need a political leader. What they need is a wise leader who can create peace for different people of many ethnicities and religions. It is essential to cultivate the social capital to prevent rumor, tensions and conflicts. The social capital consists of effective channels of communication, an integrative climate and an effective system of dispute settlement. Just economic structures and a critical number of peace building leaders are also required.

\section{DEESCALATION, RECONCILIATION AND PEACE BUILDING}

\section{The Role of the Communal Leaders and Civil Society}

During the conflict, many people and leaders were involved in the conflict. Post-conflict, many leaders and people from different elements of society tried to deescalate the situation. Deescalating the conflict needed engagement among many individuals who had taken part in the conflict. It also needed a neutral figure or group to be a mediator. Many factors deescalated the conflict in North Maluku. The most important aspect was the role of the leader. As a communal society, people in North Maluku have their leaders. These leaders belong to different groups based on ethnicity, religion, and civilian activities. These leaders played a major role in deescalating the conflict and peacebuilding.

\section{The Role of Religious Leaders}

Some religious leaders took part in the conflict; however they also performed a significant role in reconciliation and peace building. Ms. Efrida Erna Ngato said that the role of the pastor in the Church and imam in the Masjid were significant in deescalating the conflict. She remembered during the conflict there were many people still praying together in the Church or Christian houses. Pastors repeated the significance of 
forgiveness and peace. Imam in the Masjid also demanded Muslims forgive and make apeaceful reconciliation (Interview with Ms. Ngato, 2013).

"During prayers my pastor always said, 'every day we pray a prayer that Jesus taught us, forgive us our sin as we forgive those who sin against us.' This time is a time to test our faith: are we brave enough to forgive people who against us as we pray." (Interview with Ms. Ngato, 2013). According to Mrs. Efrida, this invitation had astrong impact on the Christian people. Since the prayer and the advice to forgive others was heard, people, step by step, calmed down and changed their inner heart. Deep down in people's heart, forgiveness was growing. Many people did not want the conflict to happen again. The preaching of the imams in Masjids also asked Muslims to forgive and make efforts towards peace building. Religious leaders were together looking for peace.

Religious leaders, together with local government and ethnic leaders, tried to make gatherings among the people in conflict to meet and greet. Meetings and having a meeting in a brotherhood are ways to reduce high tempered situations and conflict. These sessions gradually become good strategies to build friendship and reconciliation among the people. In some places where wars occurred between two groups, such as the Districts of Ibu, Loloda, Bacan, Jailolo, and Morotai, many meetings were held.

\section{The Role of Government Leaders}

In 2000, the President of Indonesia gave a special task to the Vice President to build peace and reconciliation in Maluku and North Maluku. The Vice President (Megawati Sukarno Putri) came to Maluku to reconcile the two groups who were engaged in conflict. The Vice President visited Ternate, Galela, Tobelo, and Kao. She appealed to the people to reconcile and make peace. She said without reconciliation Maluku, which had been developed for centuries would collapse. Many people received her appeals. Two groups from the Muslim and Christian communities in Mamuya and Tobelo accepted her invitation very well. Although the visit of the Vice President had a positive impact in building reconciliation, Jihadists from Java came to Maluku some months later. They attacked Christians in many places so the situation worsened. The conflict escalated again. (Jan Nanere, 2000).

Local government, together with religious leaders and NGOs tried to reconcile people. The local government finally found a good way to reconcile people from different background and ages. Maluku, especially Halmahera has plenty of high quality bamboo. The people of Halmahera are also well known for their expertise of plaiting. They are very good at making souvenirs and many kinds of tools from bamboo. They can make kitchen sets, hats and other souvenirs.

The local government tried to gather people and asked them to make plaiting bamboo their handicraft. Many people from many different backgrounds gathered as a group to plait bamboo. Many housewives, young people, and men gathered to plait bamboo. These occasions effectively made them became creative and relax because they were in a brotherhood with others.

The plaited bamboo was sold to others. The local government helped them to make and sell their handicrafts in many places even on other islands. These economic activities helped people earn an income after many markets and fields were smashed because of the conflicts.

\section{The Role of Non-Government Organizations (NGOs)}

There were several Non-Government Organizations (NGOs) in Maluku and Halmahera during and after conflicts. They tried to help victims. There were two NGOs which played important roles in reconciliation and peace building in Halmahera. They were World Vision International Indonesia (WVII) and the United States of America of Indonesia Development (USAID). WVII focused on helping with the emergency needs of victims, such as food, clothes, and medicine. USAID helped victims to rebuild houses, by giving materials such as cement, nails, roofing, and wood. These aids were critical to the victims during and after the conflict because many people lost their homes and did not have any food to eat. 


\section{The Role of Grassroots People and Cultural Strategies}

During theconflict, many people from Halmahera and other islands tried to help victims and create reconciliation. One of the significant efforts was the founding of groups which promoted reconciliation and peace building. There were several groups which were founded and gave different contributions to peace building and reconciliation. Two such groups were Forkom PKH and Lembaga Ketahanan Masyarakat Halmahera (LKMH) who promoted a program called Halmahera Baku Dapa, a gathering of Halmahera's People. However, those two groups did not play a very important role in reconciliation because they only succeeded increating gatherings among Christians. Before making gatherings with Christians and Muslims, situations became worse after the coming of the Jihadists.

Cultural strategies effectively deescalated theconflict. Sometimes stories can bond relationships. Many people of Halmahera believe they originally came from one big family in Talaga Lina (Telaga Lina). Their ancestors once lived in Talaga Lina and stayed in "a big home" called Hibua Lamo. This belief has often been told. Hibua Lamo and Talaga Lina were promoted again by many people from grassroots and from community leaders. Some groups and local governments tried to use this story, but people saw that the initiative was from above or by the leaders. People became suspicious about whether their leaders were using their support for their own personal gain, such as for the extension of the district North Halmahera from the province of North Maluku to the Province of North Sulawesi. Hibua Lamo was effective at building one identity among people who were in conflict. They saw others as their brother again. Eventually, people could meet other groups without fighting (S.S. Duan, 2008: 5I).

\section{SYNTHEZING DEESCALATION AND PEACE BUILDING}

\section{Stalemate and De-escalation}

Stalemate and de-escalation of the conflict grew because of various reasons. Pruit and
Rubin say there are five strategies people use to engage with a conflict. These are contending, inaction, yielding, withdrawing, and problemsolving (Pruit 2003:130). Looking at the case of stalemate and de-escalation in North Maluku, we can see that some groups who were fighting during the conflict and trying to kill others also sought to withdraw from the situation. The Makian people after being attacked were physically removed from the conflict area. They moved to other places, even though they were still fighting with the Pagu.

After the conflict, people tried finding a problem solving solution together. Communication and contact between many people from different backgrounds was needed. This is critical to resolving issues. Pruit says that communication and contact enable people to understand others. However, it is not easy to achieve communication and contact. As Forkom $P K H$ and LKMH did when they tried to call a gathering. People were not ready to meet and communicate. They were still suspicious and distrusted one another. They also saw these gatherings as having a hidden agenda. Communication and contact to build peace and stop conflict needs other solutions. Communication is not effective when people are still distrustful.

\section{Civil Society Engagement in Peace Building}

Looking at the ways communal leaders and grassroots people built peace and deescalated the conflict, we can see that several methods were used in post conflict North Maluku. Tadjoeddin mentions there are three civil society mechanisms; these are intercommoned civic engagement, self (community) policing, and elite integration (Tadjoeddin 2004:I-2).

The first mechanism of engagement in North Maluku was self or community policing. Communal leaders, especially religious leaders created public policies not to fight and pushed them to forgive and create peacebuilding. As the imams and pastors did, they talked about forgiveness and peace building. This self-community policing, as Varshney states, is important to de-escalate theconflict. This engagement was exercised by elders, community organizations and the public (Tadjoeddin 2004:5). Community 
policing was also established in North Maluku through the story about one big house or Hibua Lamo. Hibua Lamo (the Big House) is a place that is often used by the public of Tobelo to hold a meeting to discuss matters concerning the community of North Halmahera. It is the place for making and formulating policies and norms to be followed by communities in order to get harmony and peace. Another function of the Hibua Lamo is as a place to resolve any issues encountered or experienced by the communities of Tobelo. Recently Hibua Lamo became the basis of the reconciliation process based on traditional values. It had a significant contribution to the realization of reconciliation between the two warring factions. In a relatively short time refugees from some areas were able to return home without having to wait for the government program of returning IDPs (internally displaced persons).

The intercommunal civic engagement was established in North Maluku after the conflict. Communal leaders and NGOs tried to make intercommunal meetings. This engagement was not only about making communication and contact but they also sought to make people in conflict met and work together, for example plaiting bamboo. Intercommunal civic engagement made people meet and see others as their partner. Elite integration supported these engagements. Communal leaders, including government leaders, united to push people into building peace and reconciliation.

\section{CONCLUSION}

Looking at the conflict of NorthMaluku, we can see that many aspects escalated the conflict, which was a horizontal conflict. The escalation was not only caused by religious issues but by many social aspects. It was related to local political decisions, the conflict in Ambon and the role of provocateurs, who had their own reasons to escalate the dispute. The causes of the conflict were interconnected and made situation worse. In short, the conflict escalated and divided people into their identities. Political reasons about the extension of territory made people divide into groups with different interests. It was economic and political reasons which made them suspicious of one another. They were also differentiated by their tribes; one is Makian and the other is Pagu. These tribes have different interests and politica laspects which broadened the conflict into an ethnic one. Later on, their religion became their identity. This conflict then became areligious conflict. The escalation increased because many people from outside came and made religion the reason to fight.

De-escalation and peacebuilding was not easy because the causes of the escalation were varied. The role of communal leaders were important in deescalating the conflict and peacebuilding. Communal leaders, such as religious leaders, local government leaders and ethnic leaders played a significant role. The de-escalationand the consolidation of peace required both intracommunal and intercommunal solutions. First, communal leaders themselves had to agree to de-escalate the conflict. Afterwards, self or internal policing played important role In deescalating clashes within each group. The communal leaders were important to achieve self-policing within each cluster. Self-policing, then continued by intercommunal engagement. All engagement tried to de-escalate the conflict. After many years the conflict has ended, it was a challenge to rebuild trust among people.

\section{REFERENCES}

Abrahms, Max. (2008).What terrorists really want: Terrorist motives and counterterrorism strategy. International Security 32 (4), 78-105.

Al Qurthuby, Sumanto. (20I2). Indonesia's Religious Conflict and Grassroots Agency for Peace. Peace Research, 44/2, I35-I62.

Amal, M. Adnan. (2013). Tobelo Tempo Doeloe. Halmahera Utara: Dinas Pariwisata dan Kebudayaan Kabupaten Halmahera Utara.

Appleby, R. Scott. (20I2). Religious Violence: The Strong, the Weak, and the Pathological. Practical Matters, 5, I-25

Appleby, R. Scott. (2000). The Ambivalence of the Sacred: Religion, Violence, and Reconciliation. Rowman \& Littlefield.

Barron, Patrick, Azca Muhammad Najib \& Susdinarjanti, Tri. (2012). Seusai Perang Komunal: Memahami Kekerasan Pasca-Konflin di Indonesia Timur dan Upaya Penanganannya. 
CSPS Books: Pusat Studi Keamanan dan Perdamaian, Universitas Gadjah Mada.

Bromley, David G., and Melton, J. Gordon. (2002). Cult, Religion, and Violence. Cambridge: Cambridge University Press.

Brown, Seyom. (I994). The Causes and Prevention of War. St. Martin's Press.

Budiman, Martin. (2009). Musuhku adalah Saudaraku. Thesis, Salatiga: Duta Wacana University.

Duan, S.S. (2008). Hein dan Hibualamo, Tobelo Pos Menelusuri Jejak Kepemimpinannya. Halmahera Utara: Tobelo Pos dan Pemda Kabupaten Halmahera Utara.

Duncan, Cristopher R. (2005). The Other Maluku: Chronologies of Conflict in North Maluku. Indonesia, Southeast Asia Program Publication at Cornel University, Io, 53-80.

Hafez, Mohammed M., and Quintan Wiktorowicz. (2004).Violence as Contention in the Egyptian Islamic Movement. Islamic Activism: A Social Movement Theory Approach, 6I-88.

Hasyim, Azis, Dharmawan, Arya Hadi \& Juanda, Bambang. (20I0). "Analisis Perebutan Wilayah di Provinsi Maluku Utara," in Sodality: Jurnal Transdisiplin Sociology, Komunikasi, dan Ekologi Manusia, pp. 293-308.

Hasenclever and Rittberger. (2000). Does Religion Make a Difference? Theoretical Approaches to the Impact of Faith on Political Conflict. Millenium -Journal of International Studies, No. 3 .

Jurgensmeyer, Mark. (2000). Terror in the Mind of God-The Global Rise of Religious Violence. Los Angeles: University of California Press.

Kimbal, Charles. (2002). When Religion Becomes Evil. New York: HarperCollins Publishers, Inc.

Klinken, Gerry van. (2007). Communal Violence and Democratization in Indonesia, Small Town Wars. New York: Routledge.

Liliweri, Alo. (2005). Prasangka dan Konflik, Komunikasi Lintas Budaya Masyarakat Multikultur. Yogyakarta: LKiS.

Martanto, Ucu. (20I2). "Ruang dan Konflik Wilayah: Cerita dari Enam Desa. Paper No. 3. Universitas Gadjah Mada: Center for Security and Peace Studies.

Muhammad, Syahril. (2013). Masyarakat Ternate, Pergulatan Tradisi dan Modernitas. Yogyakarta: Penerbit Ombak.

Nanere, Jan (et.all), (200o).Kerusuhan Maluku Seri Pertama: Halmahera Berdarah. Ambon:
Yayasan Bina Masyarakat Sejahtera dan Pelestarian Alam (BIMASPELA).

Rubin, Jeffrey Z., Dean G. Pruitt, and Sung Hee Kim. (I994). Social Conflict: Escalation, Stalemate, and Settlement. McGraw-Hill Book Company.

Tadjoeddin, Mohamad Zulfan. (2004). Civil Society Engagement and Communal Violence: Reflection on Various Hypotheses in the Context of Indonesia. Administration and Change, 42, I-I8.

Tahun, Martin. (2007). The Ambiguity of Religion, A Study of the Ambon Conflict, I999-200I. Thesis. Yogyakarta: Center for Religious and Crosscultural Studies.

Varshney, Ashutosh, (2003).Ethnic Conflict, and Civic Life Hindu and Muslims in India, Yale University Press.

Wilson, Chris. (2005). The Ethnic Origin of Religious Conflictin North Maluku Province, Indonesia, I999-2000. Indonesia, Southeast Asia Program Publication at Cornel University, 69-91.

Wisudo, Bambang. (20Io). Bertaruh Nyawa Merajut Damai, Kisah Gerakan Peringatan Dini Konflik Ambon. Jakarta: Yayasan TIFA. 